\title{
The role of the Occupational Court of Latvian Medical Association in the system of legal liability of medical practitioners
}

\author{
Aldis Liepins*, Osvalds Joksts, and Janis Vetra \\ Rīga Stradiņš University, Latvia
}

\begin{abstract}
The article The Role of the Occupational Court of Latvian Medical Association in the System of Legal Liability of Medical Practitioners describes the system of professional liability of medical practitioners, analyzing in details one of the institutions, which ensures professional liability of doctors and dentists - the Occupational Court of Latvian Medical Association. The article characterizes the position and role of the Occupational Court in the system of legal liability of medical practitioners, researches legal regulation for operations of the Occupational Court, the essence of the Occupational Court proceedings and the legal nature of decisions made in the Occupational Court. The article identifies potential problems in operations of the Occupational Court, making proposals how to eliminate the problems found out. The authors offer to expand the competence of the Occupational Court in the future. The article also touches upon such problematic issues relating to legal liability of medical practitioners as doctor's errors and medical errors, causality, etc.
\end{abstract}

Key words: occupational court, Latvian Medical Association, medical practitioners, legal liability.

\section{Introduction}

In the context of legal liability of medical practitioners it is important to single out liability of medical practitioners as specific persons subject to law for violations related to medical treatment within the meaning of Paragraph 1 of Section 1 of the Medical Treatment Law [1], and not any legal violations committed by medical practitioners. Legal liability of medical practitioners for violations may be expressed as criminal liability, liability for administrative offences, civil liability, disciplinary liability, professional liability and liability, arising from specific administrative proceedings. Professional liability of medical practitioners should be separated from other types of liability of medical practitioners. Professional liability of medical practitioners is for violations of law committed in performing their professional activity; it is imposed by a professional organization or its specialized institution. Professional liability of medical practitioners for violations of law does not exclude other types of legal liability for specific violations of law.

The aspect of professional liability of medical practitioners was researched in Latvia before in the book Medical Law [2], in which this type of liability was designated as disciplinary liability [2].

\footnotetext{
* Corresponding author: aldis.liepins@rsu. lv
} 
In the authors' opinion, disciplinary liability is one of the types of legal liability [2], but it is imposed by employers for violations of law within the framework of employment relations, and, due to its meaning and procedural reasons, it should be separated from liability imposed by a professional organization or its specialized institution.

Latvian Medical Association (hereinafter - LMA) is a professional organization established in 1988. One of the objectives of LMA is to supervise the fulfilment of professional duties of doctors insofar as they do not fall within the competence of their direct superiors (Clause G 2.7, of LMA Statute) [3]. To fulfil this objective, in 1997, following the practice of V Ein Berufsgericht in Germany [4, 25], in LMA there was formed a specialized institution - the Occupational Court. The Occupational Court is the institution of the professional organization for representatives of liberal professions, which examines the cases of malpractice, if any, committed by doctors and dentists (hereinafter referred to also as "inspected medical practitioners" as designated in the Occupational Court Statute), to whom LMA, acting on behalf of the State of Latvia, pursuant to Section 29 of the Medical Treatment Law, issued certificates (in this article the term "certification" is understood to include certification, re-certification in basic specialty, sub-specialty, additional specialty, or in applying treatment or diagnostic methods). The purpose of creating the Occupational Court is inseparably associated with the aspect of certification of doctors and dentists, aiming to form a mechanism for the annulment of certificates awarded, finding out violations in professional activities of doctors or dentists. Malpractice entails liability for damage caused to patients in performing professional medical activities [5].

Since 2011 the Occupational Court has examined 4 cases, with 3 cases being in the process of examination. Within the time period till 2017 (inclusive) in a few situations it was refused to accept cases for examination due to the period limitation expired (period of limitation for examination of the cases of malpractice is 2 years). In 2012, in one case there were examined 23 episodes, in part of which there were identified violations in professional activities of a medical practitioner, in all other cases malpractice was not detected [6].

The purpose of this article is to identify the position and role of the Occupational Court in the system of legal liability of medical practitioners in Latvia, to research legal regulation for operations of the Occupational Court, to make conclusions on the essence of the Occupational Court proceedings, and to identify potential problems in operations of the Occupational Court, making proposals how to eliminate the problems detected. The authors will offer to expand the competence of the Occupational Court in the future. The article will also touch upon problematic issues relating to doctor's errors and medical errors.

\section{The role and position of the Occupational Court in the system of legal liability of medical practitioners}

In Latvia, medical practitioners are "the persons, who have a medical education and who are engaged in medical treatment" (Paragraph 2 of Section 1, Medical Treatment Law), i.e.:

- doctor and dentist;

- functional specialists: physiotherapist, occupational therapist, riding therapist, technical orthopedist, audio speech therapist, food specialist and art therapist (art therapy specialist);

- assistant functional specialists: assistant physiotherapist and assistant occupational therapist, assistant riding therapist;

- head nurse, military paramedic, assistant dentist, assistant radiologist, assistant dentist, radiographer, massage therapist, cosmetologist, beauty specialist in cosmetology, biomedical laboratory technician, chiropodist and dental technician, nurse, assistant nurse, dental nurse and dental hygienist. 
The status of a medical practitioner in Latvia is characterized by a number of factors: medical education, acquiring and recognition of professional qualification, which is expressed as certification and entering in the Register of Medical Practitioners and Medical Support Staff maintained by the Health Inspectorate (Section 26, Medical Treatment Law [1], and the Cabinet Regulation No. 943 of December 18, 2012 Medical Practitioners Certification Procedures (hereinafter - Certification Regulation) [7]).

In Latvia, certification of medical practitioners is performed by:

- the Certification Council of Latvian Medical Association (LMA);

- the Certification Council of Latvian Association of Professional Organizations of Medical Practitioners (LAPOMP);

- the Certification Council of Latvian Nurses Association (LNA).

The certification council is a collegial structural unit formed by the certification institution (LMA, LAPOMP, LNA) (7-17 members).

In addition to the function of certification, certification councils have the right to annul certificates issued to medical practitioners in the cases set out in the Certification Regulation, incl. in case if the certification institution becomes aware of serious violations of regulatory enactments, regulating professional activity and ethical norms, committed by medical practitioners in their professional activity (Clause 79.4). Proposals to annul certificates issued to medical practitioners are submitted in this case to:

- the Certification Council of LMA - by the Occupational Court or Ethics Commission;

- the Certification Council of LAPOMP - by the Ethics Commission of LAPOMP;

- the Certification Council of LNA - by the Ethics Commission of LNA.

Therefore, it should be concluded that the Occupational Court like certification councils, Central Medical Ethics Commission and Ethics Commissions of certification institutions is the institution, examining violations committed by medical practitioners in relation to their professional activity, thus ensuring professional liability of medical practitioners.

Pursuant to the Occupational Court Statute, the Occupational Court makes decisions and the above "proposal" to the certification council of LMA "takes the shape" of a decision.

\section{Malpractice and the concept of the Occupational Court proceedings}

Chairman of the Occupational Court Jazeps Basko, Dr. med., defines professional liability of medical practitioners as liability for damage caused to patients, performing their professional activities [5]. According to the Occupational Court Statute, the Occupational Court examines the cases of malpractice of medical practitioners, to whom LMA has issued certificates (Clause 1). They are doctors and dentists. Malpractice is understood to include violations in professional activities committed by medical practitioners, resulting in damage to patients or other persons in the aspect of health care (Clause 3, Statute). As is evident "malpractice" is defined rather broadly.

Analyzing the legal definition of malpractice included in Clause 3 of the Occupational Court Statute, the question arises how other persons in the sphere of healthcare could suffer due to violations in professional activities committed by medical practitioners. The authors of the article failed to find an answer to this question.

Up to now, the contents of malpractice has not been studied in the legal literature. It is important to define the contents of malpractice, since persons subject to the Occupational Court jurisdiction must know (or have an opportunity to know) for what they can be held liable, persons must have an opportunity to correct their behaviour in accordance with their knowledge so as not to be held liable. 
Potential causes of malpractice can be: (1) casualty; (2) error; (3) lacking professional knowledge and/or skills; (4) negligence; (5) improperly selected medical examination or treatment method [5]. These potential causes of malpractice can overlap or be combined.

Reasons for causing damage to patients like activity or non-activity of a doctor can include also other factors. Examining the cases of violations, the Occupational Court evaluates inter alia: professional activity of a doctor, operations of a structure, financial and technical support, the level of professional training of a technical performer of manipulations (this medical practitioner, e.g., a nurse may be not subject to the Occupational Court jurisdiction), the level of a doctor's guilt and professional liability of a doctor [5].

In the authors' opinion a list of these reasons could be supplemented and optimized, but it is not the purpose of this article. At the same time, it is evident that the causes of damage caused to patients can be different. Therefore, the aspect of causality should be discussed.

Causality has been defined since the Roman times by the conditio sine qua non formula (from Latin "precondition without which something is impossible") [8]. Also nowadays, this formula helps identify causes (circumstances), without which harm could not have taken place, therefore - which are in causal relation with consequences, potentially also with malpractice. The contemporary legal concept is constantly developing, with the causality of these formulae being defined broader in the doctrinal document The Principles of European Tort Law [9], hereinafter - PETL, which provides for the following types of causes: equally important (concurrent) causes (Section 3: 102, PETL), alternative causes (Section 3: 103, PETL), potential causes (Section 3: 104, PETL) and uncertain partial causation (Section 3: 105, PETL) [9]. These methods of identifying causality stated in the Principles of European Tort Law should be applicable, finding out causal relation between harm and activity or nonactivity of medical practitioners in the process of medical treatment. These types of causality are especially important in the cases if activity or non-activity performed by inspected medical practitioners is really or presumably combined with other factors, e.g., system error, organizational error, patient attitude error (in observance of prescribed therapy), etc.

Malpractice can be committed only by professionals, who possess adequate knowledge, skills and practices, therefore, in the authors' opinion, casualty could not be the cause of malpractice.

Discussing potential doctor's errors, it is important to realize the nature of an error. Dr. iur, assoc. professor A. Lieljuksis classified errors in the process of medical treatment as follows: deontological errors, diagnostic errors, medical treatment errors, iatrogenic errors [2].

Deontological errors (related to medical practitioners' communication and attitude towards patients and violation of behavioral norms towards patients) can also be at least in uncertain partial causation (Section 3: 105, PETL) relating to damage caused to the patient's health, since it is admitted in the medical science that psychosomatic mechanisms can lead to worsening of a patient's health [10].

It is a disputable matter whether diagnostic errors always result from unprofessional actions of medical practitioners. The cause of the above errors can be related to failure of diagnostic equipment, or inadequate knowledge or research, or other causes, including nonprofessional actions of medical practitioners.

A. Lieljuksis, Dr. iur, assoc. professor, relates medical treatment errors to non-qualitative medical treatment process [2].

Discussing such cause of malpractice as negligence, the authors believe that they are a definite category of medical treatment errors, which can be additionally characterized by the forms of guilt as laid down in the Criminal Law - criminal negligence or criminal self-confidence [11]. At the same time, potential causes of malpractice "lacking knowledge and/or skills" and "improperly selected medical examination or treatment method" can be justified and unjustified. There can be the situation where the science is not adequately 
developed or a clinical case is too complicated, but there can be also the situation where the inspected medical practitioner did not act as a "reasonable physician". The term "reasonable physician standard" is understood to imply a professional standard how any other doctor of that time would act [12]. The term "reasonable specialist" or "reasonable specialist standard" is a legal fiction $[13,14]$ whereby liability of any professional is measured and weighted.

In view of the fact that nowadays a patient's healthcare is not ensured by the same doctor, but by an organized team of the system, which also depends on various systemic decisions, actions of inspected medical practitioners are no longer classifiable by means of conditio sine qua non.

A short time ago there was information in periodical editions that two persons died, because on off-days "the artificial blood circulation specialist was not on duty due to shortage of money" [15].

Nowadays, knowledge of medical errors is gradually expanding. Medical errors are defined as a mistaken activity or non-activity of a medical practitioner, or noninvolvement in planning or implementation of activities, what led or can lead to undesirable consequences [16]. Other authors define medical errors in the same way - as a failure in the process of medical treatment, which causes or can cause damage to the patient [17]. There are different views how to perceive medical errors - as a very serious threat to patients' safety [17], and as those, of which the largest portion of medical errors cause no damage to patients, however they can lead to death or chronic health problems [18]. It is emphasized that a medical error is not a doctor's error. Sometimes it is not easy to establish whether undesirable results of treatment are due to errors, or a critical condition of the patient, or disease-related or natural complications. In the context of safety of patients it is much more efficient to focus not on the identification of errors, but on the analysis of the outcome of treatment, when it did not give the expected result [18]. A generally accepted fact that is that it is natural for a human being to make mistakes, that it is impossible to change a human nature, but it is possible to change the environment, in which people work [5]. Therefore, in the modern medicine, in the developed countries there was introduced a non-penal analysis of the error reporting (study) system and risks, aiming to identify improvement-oriented activities. This system is being introduced in Latvia as well. The project cannot be implemented for one day, one month or one year. Attitude of medical practitioners should be changed, conquering their fear to be punished. The same is confirmed by Evija Palceja, the Head of the Patient Safety System of the Children's Clinical University Hospital, stating that difficulties in the introduction of this system are experienced in post-soviet countries with traces of a forceful guilt and punishment culture and a legal culture prevailing over approach [18]. Nonetheless, despite the aforesaid, in the countries, which are not post-soviet countries and in which there is no forceful guilt and punishment culture, doctors (in the context of Latvia - medical practitioners) commit violations, for which they are punished. These are such violations, in which there are no systemic components when employees intentionally violate safety procedures, in the authors' opinion - regulations, guidelines, algorithms [18]. It is known from non-documented talks with professionals in the sector of medicine that in the countries, in which this system is developed, there exists a highly developed system of medical procedures and manipulation guidelines, what can't be said about Latvia. Therefore, in Latvia, in order to analyze medical errors and at the same time malpractice, the "reasonable doctor's standard" should be applied.

It should be concluded from the aforesaid that, analyzing potential malpractice, it is important to weigh and measure it by applying the "reasonable doctor's standard", analyzing it as interrelated with the system and organizational performance drawbacks and separating its causality from consequences of malpractice committed by other medical practitioners, as 
well as from the cases, which were unavoidable at the present level of development of the medical science.

As it was mentioned in the Introduction, for committing malpractice in the circumstances set out in law, doctors may be held liable, bearing other kinds of legal liability.

As it is evident, the Occupational Court does not limit itself to a superficial investigation, it searches causes much more thoroughly. Head of the Occupational Court Jazeps Basko states that the Occupational Court is not only a body imposing punishments, its purpose is to make a conflict-settling, instructional, educational and in any case an adequate assessment of professional activities of doctors [5]. As it arises from the aforesaid, in its activities the Occupational Court observes the principle of multi-causality of potential malpractice and in the context of malpractice analyzes multi-factoriality.

In all high-tech sectors expert examination of professionals is performed only by the professionals of the relevant sphere. Establishing guilt of medical practitioners in case of criminal, administrative or civil liability, expert examination of medical practitioners' activities is carried out by experts involved by the expert examination institutions, State Forensic Medicine Expert Examination Centre or Health Inspectorate, or a court (institution). Within the framework of the Occupational Court proceedings, expert examination is performed by the sectoral professionals elected among doctors and dentists at the conference of LMA.

The literature offers several explanations of the term "expert examination"; studying them, it should be concluded that, first, expert examination involves examination of any issue in order to present an opinion, second, special knowledge is required to conduct expert examination, third, in the course of expert examination, a special research is made, fourth, the result of expert examination is documented according to a special form - expert examination form. In the process of expert examination various tasks of practical value are performed: there can be acquired new knowledge of objects and phenomena, there can be checked or exacted knowledge acquired before on objects and phenomena, in the form of a forecast there can be assessed the development of any events, etc. [19]. The Occupational Court Statute regulates the relevant aspects in order to ensure independence of the Occupational Court, stating that for the purpose of examination of cases the head of the Occupational Court, as possible, designates judges, who do not represent the same professional association/society as is represented by the inspected medical practitioner (Clause 30, Statute), and involves 3 experts from professional associations (Clause 29, Statute). Independence like special knowledge is a very important factor for expert examination.

Therefore, it should be concluded that the essence of the Occupational Court proceedings is the expert examination of doctors' professional activities.

The Occupational Court proceedings are equated with judicial inquisition. It is confirmed by:

- the procedure for the collection of evidence, respectively, it is stated in Clause 16 of the Occupational Court Statute: "If the Head of the Occupational Court believes that additional information is required, he imposes a duty on the reporting judge to provide it" [20];

- as laid down in Clause 43 of the Occupational Court Statute, "The duty of LMA structural units is to further the process of investigation and to cooperate with the Occupational Court to find the truth".

The Occupational Court plays an important role in the system of professional liability of medical practitioners. The enhanced value of the Occupational Court is due to its status of a non-state, collegial and competent institution, which is capable of performing a fair examination and assessment of violations in professional activities of medical practitioners. 


\section{Problematic issues related to the procedural order of the Occupational Court}

The Occupational Court acts in accordance with the Statute approved at the conference of LMA on May 6, 2011.

Within the framework of this Chapter there will be discussed problematic issues of procedural nature related to plaintiffs and defendants, as well as probable non-conformity of the Occupational Court proceedings with the principles of Favor defensionis.

\subsection{Applicants}

As it was mentioned, cases are commenced in the Occupational Court on the basis of proposals (applications) submitted by the following persons or institutions: patients and their relatives, medical practitioners (requesting to commence a case against themselves in order to protect their honor and dignity), Ministry of Health, Health Inspectorate, public prosecution offices, courts.

The last four applicants are, inter alia, institutional applicants, who unlike the first two types of applicants have no their personal interests, which would be required to protect in the Occupational Court, they act for the protection of legal interests of the entire society - in the context of the Public Law. In the context of the Public Law the following principle applies it is permitted to do only what is laid down in legal norms [21]. Clause 78 of the Certification Regulation sets out a number of institutions, which may submit to the Certification Council of LMA a proposal for the annulment of a certificate. However, neither a public prosecution office, nor a court, is included in a list of these institutions. Furthermore, the right of these institutions to bring an action in the Occupational Court is not specified in special legal norms, regulating operations of a public prosecution office and a court in the context of the Public Law. Without going into details, it is evident that the right of a public prosecution office or a court to apply to various institutions and request data required for proceedings registered in their record-keeping system is not contestable. However, in a specific case, keeping in mind the competence of the Occupational Court to make decisions of specific contents in the context of the Public Law, it should be concluded that neither a public prosecution office, nor a court of general jurisdiction or an administrative court have or can have a subjective or an objective interest, and thus the right to submit to the Occupational Court an application, requesting to make any specific decision pursuant to Clause 76 or 77 of the Occupational Court Statute. Therefore, it should be concluded that the institutions, a public prosecution office and a court, are unreasonably included in a list of applicants as laid down in Clause 2 of the Occupational Court Statute.

Discussing interests of the institutional applicants - Ministry of Health and Health Inspectorate - it should be concluded that these institutions are specified in Clause 78 of the Certification Regulation, and their objective interest, implementing their functions determined in regulatory enactments [1,22, 23], may include the submission of applications for the annulment of certificates issued to medical practitioners, and observing the norms of Section 29 of the Medical Treatment Law, and Clause 78, Clause 79.4 and Clause 80 of the Certification Regulation as interrelated, the right of these institutions to bring an action in the Occupational Court is grounded.

A decision on what contents may request an inspected medical practitioner from the Occupational Court, protecting his honor and dignity, as it is laid down in Clause 2 of the Occupational Court Statute? Pursuant to Clause 76 of the Occupational Court Statute, the Occupational Court may recognize the inspected medical practitioner as not guilty or guilty of malpractice, or terminate investigating a case in the Occupational Court. The authors 
cast doubt on the fact that the inspected medical practitioner will even hypothetically ask to adjudge him guilty of malpractice. The medical practitioner will ask to find him not guilty of committing a malpractice. However, in the Occupational Court proceedings it can be decided that the inspected medical practitioner is guilty of malpractice. Finding the inspected medical practitioner guilty of malpractice, the Occupational Court may make a warning, a reprimand or a "proposal" to the certification institution to annul his certificate. It arises from Section 77 of the Occupational Court Statute that no other kinds of decisions are provided, if the inspected medical practitioner is found guilty of malpractice. The Procedural Law lays down the principle of "claim limits" or "accusation limits", implying a procedural "frame" for the case under adjudication. It arises from the above principle that a court is prohibited from violating the limits of claim, finding the inspected medical practitioner guilty of malpractice, warning or reprimanding him, or making a "proposal" to the certification institution to annul his certificate. Therefore, it should be concluded that the Occupational Court Statute should be supplemented with Clause 77.5 as follows: "The Occupational Court shall not make any of the decisions set out in Clause 77, if a medical practitioner being inspected applied to the Occupational Court in order to protect his honor and dignity, and the Occupational Court has found the medical practitioner being inspected guilty of malpractice."

This procedural "frame" is set out, although incompletely, in Clause 41 and 42 of the Occupational Court Statute, regulating situations related to violations not stated in a complaint/application, but found out in the course of investigation, i.e., in this case a new decision of the Head of the Occupational Court is required. Nonetheless, in this situation, if there is the new decision of the Head of the Occupational Court, it will not create a basis to adjudicate this potential malpractice, since it cannot replace a "proposal" of the persons specified in Clause 2 of the Occupational Court Statute, which is the only document to serve as a basis for commencing a case. Therefore, it should be concluded that Clause 41 and 42 of the Occupational Court Statute should be excluded.

\subsection{Defendants}

Potential defendants are doctors and dentists, to whom LMA has issued certificates. As mentioned above, nowadays in the sector of medicine liability for results does not depend only on a specific doctor or dentist, it depends on a team, which comprises also medical nurses, functional specialists, as well as other medical practitioners and medical support staff. Quite often work of the team depends on the capabilities of a medical institution relating to its financial and technical support, and personnel, as well as organization of work, direct liability for which is assumed by the administration of the medical institution, and indirect liability by the administration of the entire healthcare sector. The aforesaid situation gives rise to some problematic issues. Prior to focusing on problematic issues, it should be mentioned that, as concluded, the Occupational Court observes in its activities the principles of multi-causality of malpractice and in the context of malpractice analyzes multi-factoriality.

The first problematic issue is whether the Occupational Court's competence is not too narrow, being limited only to doctors and dentists. It is evident according to Clause 80 of the Certification Regulation that the Occupational Court is only in LMA, and not in LAPOMP or LNA. In authors' opinion a range of potential defendants of the Occupational Court should be extended, embracing also medical practitioners and medical support staff of LAPOMP and LNA, at the same time authorizing LAPOMP and LNA to delegate their representatives for work in the Occupational Court, in this case the Occupational Court Statute should be approvable also at the conferences of LAPOMP and LNA, and the Occupational Court would acquire the inter-institutional status. 
The second problematic issue is related to liability of a medical treatment institution (or its management), in which a medical practitioner being inspected is employed. If examining liability of the inspected medical practitioner or medical practitioners for potential malpractice, the Occupational Court concludes that liability probably falls within the competence of the medical treatment institution due to violations in organization of its healthcare services, in this case, in order to make such conclusion, there should be involved also a specific medical treatment institution in the status of a defendant or a third party, but only where so requested by any of the procedural parties. The reason for such involvement is definitely, first, to give the right to the medical treatment institution to argue against reproaches against it or to defend, and, second, expanding competence of the Occupational Court, to entitle it to submit a proposal to the Health Inspectorate to suspend the activities of the medical treatment institution or its structural unit or healthcare services they have provided in accordance with the procedure set out in Chapter XIII of the Medical Treatment Law. It should be noted that, to submit this proposal, a medical treatment institution is not required to acquire the procedural status, what presently is impossible in general.

As mentioned before, in the modern medicine patients are treated by a team of professionals, and it is not always possible to identify conditio sine qua non (precondition without which something is impossible) or a direct causality between damage caused to a patient and activity or non-activity of a specific medical practitioner. The solution of this situation would be to expand a range of defendants by medical treatment institutions, as well as specifying that in one case there can be several defendants - medical treatment institutions and medical practitioners. In case of its acceptance, this proposal would resolve the current challenges, when the cause of damage to a patient can be multi-factorial. In the authors' opinion, observing its inquisitively procedural and multi-competence professional nature, the Occupational Court would cope with this task.

\section{Non-conformity of the Occupational Court proceedings to the principles of Favor defensionis}

Favor defensionis is understood to include, inter alia, advantages for the defense in criminal proceedings, which in the continental Europe since the epoch of Enlightenment are known as a set of procedural guarantees for an accused in order to compensate inquisitive aspects of criminal proceedings. In accordance with the aforesaid, the "accused" is the last to testify and he has the right to the last statement, as well as some other procedural guarantees, which compensate inequality of the "accused" party, comparing with the "accusing" party. This term is interpreted in a narrow and broad sense. The narrow meaning provides for two approaches to the interpretation of the term. One of them is close to the formula - in dubio pro reo (when in doubt, for the accused), and the second one identifies these advantages as a set of additional exclusive rights of the defense (e.g., the right of the accused to the last word, etc.). Sometimes these approaches are combined. The broad meaning also provides for two approaches to the interpretation of this term. The first approach in fact equates favor defensionis with the rights to the defense in a broad sense. The second approach interprets favor defensionis as an abstract (general) procedural structure, which should additionally guarantee the right to the defense as to a much weaker party to proceedings, granting to it advantages and privileges [24]. Elements of favor defensionis are not only in criminal proceedings, but also in civil and administrative proceedings. In the authors' opinion, favor defensionis is attributable also to procedural issues in the Occupational Court.

It should be concluded that some aspects of the procedural order in the Occupational Court do not comply with this legal principle. 
Persons invited to the session of LMA Occupational Court are heard in the following sequence:

- medical practitioner being inspected,

- witnesses,

- victim.

The procedure for hearing of invited persons is indicative of limited rights of the inspected medical practitioner to the defense within the framework of favor defensionis.

Therefore, always when a case is not commenced in the Occupational Court on the initiative of a medical practitioner, the inspected medical practitioner shall make speech last, and the victim - first.

\section{Conclusions and proposals}

1. The Occupational Court like certification councils, Central Medical Ethics Commission and Ethics Commissions of certification institutions is the institution examining professional liability of medical practitioners, doctors and dentists.

2. The Occupational Court plays an important role in the system of professional liability of medical practitioners. The Occupational Court is a non-state, collegial and competence institution, capable of objective examination and assessment of violations of professional activities of inspected medical practitioners.

3. The concept of the Occupational Court proceedings is expert examination of professional activities of inspected medical practitioners. The Occupational Court proceedings are equated with judicial inquisition.

4. Nowadays a patient's healthcare is not ensured by the same doctor, but by an organized team of the system, which depends on various systemic decisions, therefore, actions of inspected medical practitioners are no longer assessable only by the conditio sine qua non formula.

5. Analyzing potential malpractice, it is important to weigh and measure it by applying the "reasonable doctor's standard", analyzing it as interrelated with the system and organizational performance drawbacks, separating its causality from consequences of violations committed by other medical practitioners, as well as from cases, which were unavoidable, and observing the present level of development of the medical science.

6. In its activities the Occupational Court observes the principle of multi-causality of malpractice and in the context of malpractice analyzes multi-factoriality.

7. A range of applicants listed in Clause 2 of the Occupational Court Statute unreasonably comprises a public prosecution office and a court.

8. The Occupational Court Statute should be supplemented with Clause 77.5 as follows: "The Occupational Court shall not make any of the decisions set out in Clause 77, if a medical practitioner being inspected applied to the Occupational Court in order to protect his honor and dignity, and the Occupational Court has found the medical practitioner being inspected guilty of committing malpractice".

9. Clause 41 and Clause 42 of the Occupational Court Statute conflict with the principle of "claim limits" or "accusation limits" set out in the Procedural Law, implying a procedural "frame" of the case under adjudication, since a new decision of the Head of the Occupational Court may not replace a "proposal" of the persons specified in Clause 2 of the Occupational Court Statute, being the only document to serve as a basis for the commencement of a case.

10. To expand the competence of the Occupational Court and a range of potential defendants, embracing also certifiable medical practitioners and medical support staff 
of LAPOMP and LNA, at the same time authorizing LAPOMP and LNA to delegate their representatives for work in the Occupational Court.

11. To expand the competence of the Occupational Court and a range of potential defendants, including also medical treatment institutions, and specifying that there can be several defendants in one case - medical treatment institutions and medical practitioners.

12. To expand the competence of the Occupational Court, entitling it to submit a proposal to the Health Inspectorate to suspend the activities of a medical treatment institution or its structural unit or healthcare services they have provided in accordance with the procedure set out in Chapter XIII of the Medical Treatment Law.

13. The procedure for hearing invited persons is indicative of limited rights of a medical practitioner being inspected to the defense within the framework of favor defensionis (advantages for the defense). Therefore, always when a case is not commenced in the Occupational Court on the initiative of a medical practitioner, the medical practitioner being inspected shall make speech last, and the victim - first.

\section{References}

[1] Medical Treatment Law, [https://likumi.lv/doc.php?id=44108 (viewed on 15.06.2017)]

[2] A team of authors, scientific edition of S. Asnevica - Slokenberga, Med. Law Court House Agency 679, 779-783, 798 (2015)

[3] Latvian Medical Association Statute, [http://www.arstubiedriba.lv/statuti/ (viewed on 15.06.2017)]

[4] Deutsche Enzyklopadie about Occupational Court, http://www.enzyklo.de/ Begriff/Berufsgericht (viewed on 15.06.2017)

[5] Interview with Dr. Jazeps Basko, Head of the Occupational Court, Latvian Medical Association, on 21.02.2017 (non-published)

[6] Interview with Elita Viksne, lawyer of Latvian Medical Association, on 04.04.2017. (non-published)

[7] Cabinet Regulation No. 943 Medical Practitioners Certification Procedures of December 18, 2012 [https://likumi.lv/doc.php?id=253782 (viewed on 15.06.2017)]

[8] S.D. Ferrara, Malpractice and Medical Liability (Springer-Verlag Berlin Heidelberg, 2013), 99-100

[9] The Principles of European Tort Law, [http://www.egtl.org/Principles (viewed on 26.09.2016)]

[10] G. Ancane, World Psychol. 1, 38-43 (2004)

[11] U. Krastins, V. Liholaja, A. Niedre, Scientific and Practical Comments to the Criminal Law. Part I (AFS, Riga, 2003), 71-76

[12] P.G. Jr Peters, J. Health Law 34(1), 105-19 (2001)

[13] M. Riga, Impact of Medical Errors and Malpractice on Health Economics Quality, and Patient Safety (IGI Global, USA, 2017), 145

[14] M. Mullner Ross, Encyclopedia of Health Services Research (SAGE Publications, Inc., Chicago, 2009), 635

[15] G. Nagle, To Die, Because It Is Holiday [http://www.irlv.lv/2017/4/12/ nomirst-jo-brivdiena (viewed on 15.06.2017)]

[16] E.D. Grober, J.M.A. Bohnen, Can. J. Surg. Can J Surg. 48 (1), 39-44 [https://www.ncbi.nlm.nih.gov/pmc/articles/PMC3211566/ (viewed on 15.06.2017)] 
[17] J.K. Aronson, Br. J. Clin. Pharmacol. 67(6), 599-604, 2009) [https://www.ncbi. nlm.nih.gov/pmc/articles/PMC2723196/ (viewed on 15.06.2017)

[18] E. Palceja, Latvian Doctor 3(39), 76-82 (2017)

[19] E. Nimande, Concept and Role of Mandatory Expert Examination in Criminal Proceedings, [http://www.juristavards.1v/doc/89285-obligatas-eksper tizes-butiba-un-nozime-kriminalprocesa (viewed on 15.06.2017)]

[20] D. Ose, Evidence and Proof in the Civil Law, Doctoral Degree Thesis, [https:// dspace.lu.lv/dspace/bitstream/handle/7/5139/23437-Daina_Ose_2013. pdf? sequence=1 (viewed on 15.06.2017)]

[21] J. Neimanis, Introduction to Law (Janis Neimanis, Riga, 2004), p. 115

[22] Cabinet Regulation No. 286 of April 13, 2004 "Health Ministry Statute", [https:// likumi.lv/doc.php?id=87141 (viewed on 15.06.2017)]

[23] Cabinet of Ministers, February 5, 2008 "Health Inspectorate Statute", [https:// likumi.lv/doc.php?id=170578 (viewed on 15.06.2017)]

[24] E. Rusanovs, Jurista Vards 27, 22-31 (2015)

[25] T. Gerst, B. Hibbeler, Berufsrecht: Wenn Ärzte ihre Pflicht verletzen, Dtsch Arztebl 108 (10) (2011), [https://www . aerzteblatt.de/archiv/81252/ Berufsrecht-Wenn-Aerzte-ihre-Pflicht-verletzen (viewed on 15.06.2017)] 